\title{
HEXACO and Dark Triad Personality Traits as Predictors of Male Attractiveness in Different Relationship Contexts
}

\author{
Ana Butković ${ }^{1}$, Katarina Vatavuk ${ }^{1}$, and Anja Wertag ${ }^{2}$ \\ ${ }^{1}$ University of Zagreb, Faculty of Humanities and Social Sciences, Department of \\ Psychology, Zagreb, Croatia \\ ${ }^{2}$ Institute of Social Sciences Ivo Pilar, Zagreb, Croatia
}

\begin{abstract}
This study aimed to further investigate the perceived attractiveness of the Dark Triad (DT) personality in different types of relationships (i.e. friendship, short-term and long-term relationship) controlling for basic personality traits from the HEXACO model. The participants were 167 female students $(M=20.82$ years, $S D=1.54)$ who rated personality and attractiveness of a man with highly expressed DT characteristics $(n=91)$ or a low-scoring DT character $(n=76)$ presented in a vignette. In line with recent findings, we observed a high negative correlation between the Honesty-Humility factor and DT personality $(r=-.88, p<.001)$. As hypothesized, there was a significant difference in attractiveness ratings for the two characters in the context of different interpersonal relationships, with high DT character rated as significantly more attractive than the low DT character in the context of short-term mating. Furthermore, the hierarchical regression analysis showed that DT personality had a unique contribution in predicting attractiveness in the context of short-term relationship, after controlling for the basic personality traits.
\end{abstract}

Keywords: attractiveness, interpersonal relationships, Dark Triad, HEXACO

\section{Introduction}

The Dark Triad (DT) represents a constellation of three personality traits: Machiavellianism, narcissism, and psychopathy (Paulhus \& Williams, 2002). These traits reflect a socially destructive character with behavioural tendencies towards manipulation, deception, self-promotion, emotional callousness, and aggression (Furnham et al., 2013). However, these traits can also be appealing to others and the popular literature and media are full of "antiheroes" and "bad boy" characters who clearly exhibit the DT traits (Jonason et al., 2012). Moreover, previous research has indicated that women find men with pronounced DT traits attractive. When women were asked to rate the dating adverts written by men high or low on Machiavellianism, men low on Machiavellianism were given the highest ratings for long-term mating context, while men high on Machiavellianism were given the

Ana Butković, Department of Psychology, Faculty of Humanities and Social Sciences, Ivana Lučića 3, Zagreb, Croatia. E-mail: abutkovic@ffzg.hr 
highest ratings for short-term mating context (Aitken et al., 2013). In Carter et al. (2014) study character with high DT traits was rated significantly more attractive to women than the study character with low DT traits, even when controlling for the effects of the Big Five traits. However, attractiveness was rated in general, not in specific relationships. Jonason et al. (2015) investigated the attractiveness of high and low DT characters to both men and women as one-night stands, future marriage partners or as a future mother or father of the participants' children. Both men and women preferred low DT characters for long-term mating, while high DT characters were preferred for one-night stands.

DT traits are associated with both five-factor personality and HEXACO personality traits, but Honesty-Humility emerged as the best negative correlate of DT traits (Lee \& Ashton, 2005). Lee and Ashton (2014) even stated that HEXACO model effectively represents both five factors and DT, since Honesty-Humility is an opposite pole of DT traits. Recently, Hodson et al. (2018) tested the extent to which the latent Dark Triad overlapped with the low pole of the HEXACO HonestyHumility factor in both self- and peer-report data, and found meta-analytic relation to be very high, around -.95. Although previous research did investigate attractiveness of the DT traits when controlling for other personality traits, it included only Big Five traits (e.g. Carter et al., 2014; Jauk et al., 2016; Qureshi et al., 2016; Rauthmann \& Kolar, 2013). If Honesty-Humility and DT are indeed just opposite poles of the same continuum, the attractiveness of the high DT men should diminish when Honesty-Humility is controlled for. Using HEXACO model in this line of research can be used to examine the relationship between Honesty-Humility and DT traits, although findings so far would indicate that DT traits could not explain much above Honesty-Humility. In addition, Big Five model seems suboptimal in capturing individual differences in exploitation and entitlement (Lee \& Ashton, 2005; Veselka et al., 2012), and HEXACO model generally outperforms both Big Five (Bourdage et al., 2007) and the combination of the Big Five and the DT traits in predicting outcomes related to short-term mating tendencies (Lee et al., 2013).

But what makes DT traits attractive to others, and in which context? Although socially malevolent, from an evolutionary perspective, the DT traits can be adaptive, and provide reproductive and survival benefits for the individual. Life history theory is an evolutionary theory that places individuals along the continuum of reproductive strategies regarding the trade-offs they make, with those oriented more towards mating having a fast life strategy, and those oriented more towards parenting having a slow life strategy (Kaplan \& Gangestad, 2005). Generally, fast life history seems to be more adaptive for men than women, and men consistently score higher on DT traits (e.g. Jonason et al., 2009). Given that previous research demonstrated that those high on DT are oriented towards short-term relationships, unrestricted sociosexuality and more mating opportunities in different countries (e.g. Jonason et al., 2009, 2017; Jonason, Valentine et al., 2011), it is not surprising that researchers have postulated that the DT represents a fast life strategy (Jonason et al., 2010). Honesty-Humility was found to correlate with slow life history strategy (Manson, 2015; Strouts et al., 
2017), as well as positively with long-term mating orientation and even more so negatively with short-term mating orientation (Strouts et al., 2017).

Finally, people might prefer different characteristics in different types of relationships, and DT traits could be more valued in short-term relationships. Sprecher and Regan (2002) examined the degree to which various characteristics are desired in five types of relational partners: casual sex partner, dating partner, marriage partner, same-sex friend, or opposite-sex friend. They found that participants most preferred warmth and kindness, expressivity and openness, and a good sense of humour across all relationship types, but in a casual sex partner participants preferred higher levels of physical attractiveness and prior sexual experience. Lyons et al. (2012) found that women who rated male faces manipulated to be high and low on DT, rated men who were high on DT as most desirable short term partners. Holtzman and Strubbe (2013) found that DT traits were significantly positively correlated with effective adornment or the ability to present oneself appealingly, and dressing well may help to obtain romantic partners, especially shortterm ones. These findings would indicate that DT traits could be attractive to women in a short-term relationship context.

In this study, we aim to further investigate the perceived attractiveness of the DT traits in different types of relationships (i.e. short-term relationship, friendship, and long-term relationship) controlling for HEXACO personality traits. Although Lee et al. (2013) used both DT composite and HEXACO to predict short-term mating tendencies and sexual quid pro quos, they did that only by comparing HEXACO, Big Five with the addition of either DT traits or Honesty-Humility factor and Big Five measures, while they did not compare if DT traits would explain additional variance to HEXACO traits. In line with previous findings, showing that women prefer men high on DT traits in short-term relationships, and those low on DT traits in long-term relationships (Aitken et al., 2013; Jonason et al., 2015), we hypothesized that men high on DT will be perceived as more attractive only in the context of short-term relationship. Furthermore, based on the proposition that DT traits represent an evolutionary solution to the adaptive problem of reproduction (Jonason et al., 2009), we hypothesized that the DT will have a unique contribution in predicting attractiveness in the context of short-term relationship, even after controlling for the basic personality traits from the HEXACO model.

\section{Method}

\section{Participants and Procedure}

Participants were female psychology students from the Faculty of Humanities and Social Sciences in Zagreb $(N=167)$, Croatia. The age of the participants ranged from 19 to 26 years $(M=20.82, S D=1.54)$. They participated in the study during regular classes by filling in paper-and-pencil questionnaire. Participants could get one of the two different versions of the questionnaire, a version with the vignette 
describing a man with highly expressed DT characteristics $(n=91)$, and the version describing a man with low DT characteristics $(n=76)$. All the other parts of the questionnaire were identical in both versions. The participants did not know there were two versions of the questionnaire. There were no statistical differences between these two groups in age $(t(165)=0.44, p=.66)$ or study year $(t(165)=1.62, p=$ $.11)$ of participants. Using the between-group design versus a within-group design minimized transfer across conditions and made the session shorter for each group of participants.

\section{Measures}

Character descriptions of a male persona representative of a high-scoring or a low-scoring DT personality were used from Qureshi et al. (2016) study. The descriptions were translated to Croatian using back-translation and pretested on 10 females. As in Carter et al. (2014) study, questions asked participants to rate the target on narcissism ('Overvalues their own importance'), Machiavellianism ('Is manipulative') and psychopathy ('Not sensitive to others' feelings') as a manipulation check. However, since the pretest showed that the question 'Not sensitive to others' feelings' (psychopathy1) was not indicative enough for psychopathy in our culture, we added an additional question, 'Does not have guilty conscience' (psychopathy2). These items were incorporated within the HEXACO60 questionnaire to avoid the possible suggestive impact of responses on the attraction ratings and were answered on a five-point scale (from 1 'strongly disagree' to 5 'strongly agree').

As in Rauthmann and Kolar (2013) study, after reading the vignettes, participants rated the vignette person's attractiveness ('How attractive do you find this person?'), friend value ('How much would you like this person as a platonic friend?'), short-term mate value ('How much would you like this person for a shortterm sexual affair?'), and long-term mate value ('How much would you like this person for a long-term committed relationship?') on a 5-point Likert-type scale (from 1 'not at all' to 5 'totally').

The Croatian version of the HEXACO-60 questionnaire was used for the ratings on personality traits from the HEXACO model. Although this is a shortened version of the original questionnaire, it has satisfactory psychometric characteristics, and it is recommended by the authors when the time available for personality assessment is very short (Ashton \& Lee, 2009). Since the Croatian version is available only in the self-report form, for the purpose of this study we modified it to the observer report form (e.g. original item 'I would be quite bored by a visit to an art gallery' was changed to 'He would be quite bored by a visit to an art gallery.'). Participants rated the male character on a five-point scale (from 1 'strongly disagree' to 5 'strongly agree'). Personality factor scale scores were computed as sum scores, means across all items (10 items per each factor), after recoding of reverse-keyed items. In this study, the internal-consistency reliability was high (Honesty-Humility $\alpha=.97$; 
Emotionality $\alpha=.87$; Extraversion $\alpha=.83$; Agreeableness $\alpha=.86$; Conscientiousness $\alpha=.82$; Openness $\alpha=.86$ ).

\section{Results}

\section{Manipulation Check}

We started our analyses by checking the distributions. Although KolmogorovSmirnov (K-S) tests were significant for narcissism, Machiavellianism and psychopathy ratings, values of skewness and kurtosis were below the suggested values for the distributions to be considered approximately normal (Ryu, 2011). In order to establish that our vignette manipulation (the high-scoring DT personality vs. the low-scoring DT personality) was successful, $t$-tests were conducted on narcissism, Machiavellianism and psychopathy ratings. Results are presented in Table 1.

\section{Table 1}

Descriptive Statistics for Ratings on the Components of the Dark Triad, Attractiveness Ratings and HEXACO-60 ratings

\begin{tabular}{lccccccccc}
\hline & $M_{\mathrm{DT}}$ & $S D_{\mathrm{DT}}$ & $M_{\mathrm{C}}$ & $S D_{\mathrm{C}}$ & $t$ & $d$ & Skewness & Kurtosis & $\begin{array}{r}K-S \\
\text { test }\end{array}$ \\
\hline Narcissism & 4.71 & 0.54 & 2.55 & 1.10 & $15.61^{*}$ & 2.49 & -0.60 & -1.09 & $.26^{*}$ \\
Machiavellianism & 4.78 & 0.47 & 2.30 & 1.22 & $16.69^{*}$ & 2.68 & -0.65 & -1.17 & $.27^{*}$ \\
Psychopathy 1 & 3.96 & 0.91 & 2.09 & 0.93 & $13.11^{*}$ & 2.04 & -0.15 & -1.21 & $.23^{*}$ \\
Psychopathy 2 & 3.86 & 0.84 & 2.37 & 1.03 & $10.11^{*}$ & 1.59 & -0.33 & -0.85 & $.23^{*}$ \\
Attractiveness & 2.13 & 1.01 & 3.11 & 0.87 & $-6.58^{*}$ & 1.04 & 0.01 & -0.91 & $.20^{*}$ \\
Friend value & 2.43 & 1.19 & 3.82 & 0.92 & $-8.48^{*}$ & 1.31 & -0.24 & -1.01 & $.19^{*}$ \\
Short-term mate & 2.64 & 1.30 & 2.08 & 1.18 & $2.88^{*}$ & 0.45 & 0.42 & -1.00 & $.21^{*}$ \\
value & & & & & & & & & \\
Long term mate & 1.37 & 0.69 & 2.76 & 1.15 & $-9.21^{*}$ & 1.46 & 0.83 & -0.56 & $.27^{*}$ \\
value & & & & & & & & & \\
Honesty-Humility & 1.42 & 0.38 & 3.64 & 0.77 & $-22.95^{*}$ & 3.66 & 0.42 & -1.41 & $.18^{*}$ \\
Emotionality & 2.37 & 0.47 & 3.18 & 0.66 & $-8.98^{*}$ & 1.42 & 0.36 & -0.49 & $.09^{*}$ \\
Extraversion & 4.09 & 0.38 & 3.05 & 0.55 & $13.90^{*}$ & 2.19 & -0.41 & -0.59 & $.13^{*}$ \\
Agreeableness & 2.33 & 0.62 & 3.13 & 0.72 & $-7.70^{*}$ & 1.19 & 0.50 & 0.31 & $.09^{*}$ \\
Conscientiousness & 3.00 & 0.75 & 3.49 & 0.52 & $-4.88^{*}$ & 0.77 & -0.11 & -0.79 & $.09^{*}$ \\
Openness & 2.72 & 0.59 & 3.45 & 0.56 & $-8.22^{*}$ & 1.28 & -0.14 & -0.17 & .06 \\
\hline
\end{tabular}

Note. $n_{\mathrm{DT}}=91, n_{\mathrm{C}}=76$. DT - high-scoring DT character; $\mathrm{C}-$ low-scoring DT character, $K-S-$ Kolmogorov-Smirnov. ${ }^{*} p<.01$.

Levene's test for equality of variances was found to be violated for the analysis on narcissism $(F(1,165)=48.55, p<.001)$, Machiavellianism $(F(1,165)=74.68$, $p<.001)$ and psychopathy $2(F(1,165)=9.44, p=.002)$. Owing to these violated assumptions, the $t$-statistic not assuming homogeneity of variance was computed. As can be seen from Table 1 , all $t$-tests were statistically significant in the expected direction, with the high-scoring DT character rated higher than the low-scoring DT 
personality (for narcissism $t(105.03)=15.61, p<.001, d=2.49$; for Machiavellianism $t(93.23)=16.69, p<.001, d=2.68$; for psychopathy1 $t(165)=13.12, p<.001, d=$ 2.04; for psychopathy $2 t(144.03)=10.11, p<.001, d=1.59)$. In addition, all effect sizes were large effect sizes, as measured by Cohen's $d$.

\section{Attractiveness Ratings}

$\mathrm{K}-\mathrm{S}$ tests for attractiveness ratings were all significant, but as for narcissism, Machiavellianism and psychopathy ratings values of skewness and kurtosis were in the acceptable range for distributions to be considered approximately normal (Table $1)$. Four $t$-tests for independent samples were run to compare the means of the attractiveness ratings of characters from the two versions of the vignettes, in different contexts of interpersonal relationships. Results are presented in Table 1. Levene's test for equality of variances was found to be violated for the analysis on friend value $(F(1,165)=13.65, p<.001)$ and long-term mate value $(F(1,165)=35.17, p<$ $.001)$. Given the violations of Levene's test for homogeneity of variances, $t$-tests not assuming homogeneous variances were calculated for ratings on those items. The high-scoring DT character was rated as significantly more attractive than the lowscoring DT character in the short-term mating context $(t(165)=2.88, p=.004, d=$ $0.45)$, while in all of the remaining contexts the participants rated the low DT character as more attractive than the high DT character (for attractiveness $t(165)=$ $-6.58, p<.001, d=1.04$; for friend value $t(163.98)=-8.48, p<.001, d=1.31$; for long-term mate value $t(118.18)=-9.21, p<.001, d=1.46)$. For the short-term mating context, the effect size was medium, while for all of the remaining contexts the effect sizes were large, as measured by Cohen's $d$. All $t$-tests remained significant after Bonferroni correction for multiple testing $(p<.013)$.

\section{Personality Ratings}

Personality distributions for all traits except openness were significantly different from normal distributions based on the values of K-S tests, but values of skewness and kurtosis indicated again that the distributions can be considered approximately normal (Table 1). For the HEXACO-60, $t$-tests showed statistical differences in the ratings of the two characters for all of the personality traits (with Bonferroni correction $p<.008)$. Results are presented in Table 1. Levene's test for equality of variances was found to be violated for Extraversion $(F(1,165)=11.91, p=.001)$, Emotionality $(F(1,165)=8.68, p=.004)$ and Honesty-Humility $(F(1,165)=32.86, p<.001)$ and therefore a $t$-test not assuming homogeneous variances was calculated for those ratings. The high-scoring DT character was rated significantly higher than the lowscoring DT character only on Extraversion $(t(129.60)=13.90, p<.001, d=2.19)$. On Openness $(t(165)=-8.22, p<.001, d=1.28)$, Agreeableness $(t(165)=-7.70$; $p<.001 ; d=1.19)$, Conscientiousness $(t(165)=-4.88, p<.001, d=0.77)$, Emotionality $(t(132.21)=-8.98, p<.001, d=1.42)$ and Honesty-Humility $(t(105.47)$ 
$=-22.95, p<.001, d=3.66$ ), the high-scoring DT character was rated significantly lower than the low-scoring DT character. All effect sizes were large, as measured by Cohen's $d$, especially for Honesty-Humility where the effect size $(d=3.66)$ suggested that the distributions of the ratings of the two characters on Honesty-Humility factor did not overlap.

\section{Predicting Attractiveness Ratings}

In order to examine whether the vignette descriptions of DT personality have an independent contribution in prediction of attractiveness ratings after controlling for the HEXACO-60 ratings, hierarchical regression analysis was used. First, we calculated the correlations between all the variables in the study (Table 2). Version of the vignette correlated significantly negatively with Extraversion $(r(167)=-.75$, $p<.001)$ and short-term mate value $(r(167)=-.22, p=.004)$, and positively with all of the other variables in the study ( $r$ s ranging from .36 to .88 , all $p<.01$ ). Attractiveness value, friend value and long-term mate value showed a similar pattern of significant correlations with personality traits; positive correlations with all of the personality traits except for the Extraversion, for which the correlations were negative. As for Attractiveness in general, correlations with Agreeableness and Conscientiousness were not significant. For short-term mate value the pattern of correlations was opposite, there were significant negative correlations with Emotionality $(r(167)=-.22, p=.004)$ and Agreeableness $(r(167)=-.30, p<.001)$. According to Gignac and Szodorai (2016), correlations between .20 and .30 are typical in differential psychology, while correlations $>.30$ should be considered large.

\section{Table 2}

Correlations Between the Study Variables (Point-Biserial for Vignette, All Other Pearson Correlations)

\begin{tabular}{|c|c|c|c|c|c|c|c|c|c|c|}
\hline Variable & $\mathrm{H}$ & $\mathrm{E}$ & $X$ & A & $\mathrm{C}$ & $\mathrm{O}$ & Attractiveness & $\begin{array}{c}\text { Friend } \\
\text { value }\end{array}$ & $\begin{array}{c}\text { Short- } \\
\text { term } \\
\text { mate } \\
\text { value }\end{array}$ & $\begin{array}{c}\text { Long- } \\
\text { term } \\
\text { mate } \\
\text { value }\end{array}$ \\
\hline Vignette & $.88^{*}$ & $.58^{*}$ & $-.75^{*}$ & $.51^{*}$ & $44^{*}$ & $.54^{*}$ & $.46^{*}$ & $.54^{*}$ & $-.22^{*}$ & $.60^{*}$ \\
\hline $\mathrm{H}$ & - & $.60^{*}$ & $-.69^{*}$ & $.54^{*}$ & $.51^{*}$ & $.60^{*}$ & $.50^{*}$ & $.57^{*}$ & -.14 & $.65^{*}$ \\
\hline $\mathrm{E}$ & & - & $-.57^{*}$ & $.60^{*}$ & $.38^{*}$ & $.38^{*}$ & $.26^{*}$ & $.33^{*}$ & $-.22^{*}$ & $.38^{*}$ \\
\hline $\mathrm{X}$ & & & - & $-.43^{*}$ & $-.43^{*}$ & $-.40^{*}$ & $-.35^{*}$ & $-.45^{*}$ & .19 & $-.47^{*}$ \\
\hline A & & & & - & $.40^{*}$ & $.40^{*}$ & .18 & $.29^{*}$ & $-.30^{*}$ & $.36^{*}$ \\
\hline $\mathrm{C}$ & & & & & - & $.49^{*}$ & $.28^{*}$ & $.32^{*}$ & -.07 & $.32^{*}$ \\
\hline $\mathrm{O}$ & & & & & & - & $.40^{*}$ & $.42^{*}$ & -.05 & $.42^{*}$ \\
\hline Attractiveness & & & & & & & - & $.61^{*}$ & $.33^{*}$ & $.68^{*}$ \\
\hline Friend value & & & & & & & & - & .20 & $.62^{*}$ \\
\hline $\begin{array}{l}\text { Short-term } \\
\text { mate value }\end{array}$ & & & & & & & & & - & .16 \\
\hline
\end{tabular}

Note. Vignette: '1' = high DT character; '2' = low DT character; H = Honesty-Humility; E = Emotionality; $\mathrm{X}=$ Extraversion; $\mathrm{A}=$ Agreeableness; $\mathrm{C}=$ Conscientiousness; $\mathrm{O}=$ Openness. ${ }^{*} p<.01$. 
Due to some very high intercorrelations between our predictors, we run multicollinearity diagnostics. As could be expected, VIF factors were high for Honesty-Humility $(V I F=5.46)$ and version of the vignette $(V I F=5.50)$. Although some authors suggest that $V I F>5$ might be considered a cause for concern, most authors indicate that $V I F>10$ is problematic (e.g. Vittinghoff et al., 2012). Therefore, we continued with hierarchical regression analyses, and included as predictors in the first step ratings of the HEXACO personality factors, while in the second step version of the vignette. Results are presented in Table 3 . Results were similar for attractiveness, friend value and long-term mate value, with only personality traits significantly predicting attractiveness ratings. For general attractiveness, personality explained $25 \%$ of the variance, with Honesty-Humility $(\beta=.39, t=2.47, p=.015)$ and Openness ( $\beta=$ $.17, t=1.99, p=.049$ ) as significant independent predictors. Agreeableness was the only personality trait which was not significantly correlated at $p<.01$ with attractiveness $(r(167)=.18, p=.021)$ and it correlated significantly with other personality traits, so it had a suppressor effect in the regression analysis $(\beta=-.15, t=$ $-1.70, p=.092$ ). For friend value and long-term mate value, significant independent predictor was Honesty-Humility (for friend value: $\beta=.38, t=2.53, p=.012$; for longterm mate value: $\beta=.54, t=3.83, p<.001$ ), explaining $32 \%$ and $40 \%$ of the variance.

In the short-term mating context, personality accounted for $7 \%$ of the variation in attractiveness ratings. The only predictor which had an independent contribution in the first step was Agreeableness $(\beta=-.29, t=-2.98, p=.003)$. When the version of the vignette was included, prediction improved significantly $(F(1,159)=4.20$, $p=.042$ ), and $9 \%$ of the criterion variance was explained. Significant independent predictors were Agreeableness $(\beta=-.28, t=-2.87, p=.005)$ and version of the vignette $(\beta=-.36, t=-2.05, p=.042)$. Due to Honesty-Humility having a very strong correlation with the version of the vignette $(r(167)=.88, p<.001)$, but not with the criterion $(r(167)=-.14, p=.08)$, and since version of the vignette correlated significantly with the criterion $(r(167)=-.22, p=.004)$, Honesty-Humility acted as a suppressor variable in this analysis. In the first step, as in the bivariate analysis, Honesty-Humility was not associated with the short-term mate value $(\beta=.09, t=$ $0.71, p=.480)$, but in the second step its regression coefficient increased $(\beta=.33$, $t=1.93, p=.055$ ), as well as the regression coefficient of the version of the vignette variable compared to the bivariate correlation.

\section{Discussion}

This study investigated the perceived attractiveness of the DT traits in different types of relationships (i.e. short-term relationship, friendship, and long-term relationship) while controlling for personality traits from the HEXACO model adds to the literature on attractiveness of DT traits in several ways. Apart from investigating the perceived attractiveness in different types of relationships, as far as we know, this is the first study that used the HEXACO model and not the Big Five traits in this line of research. 


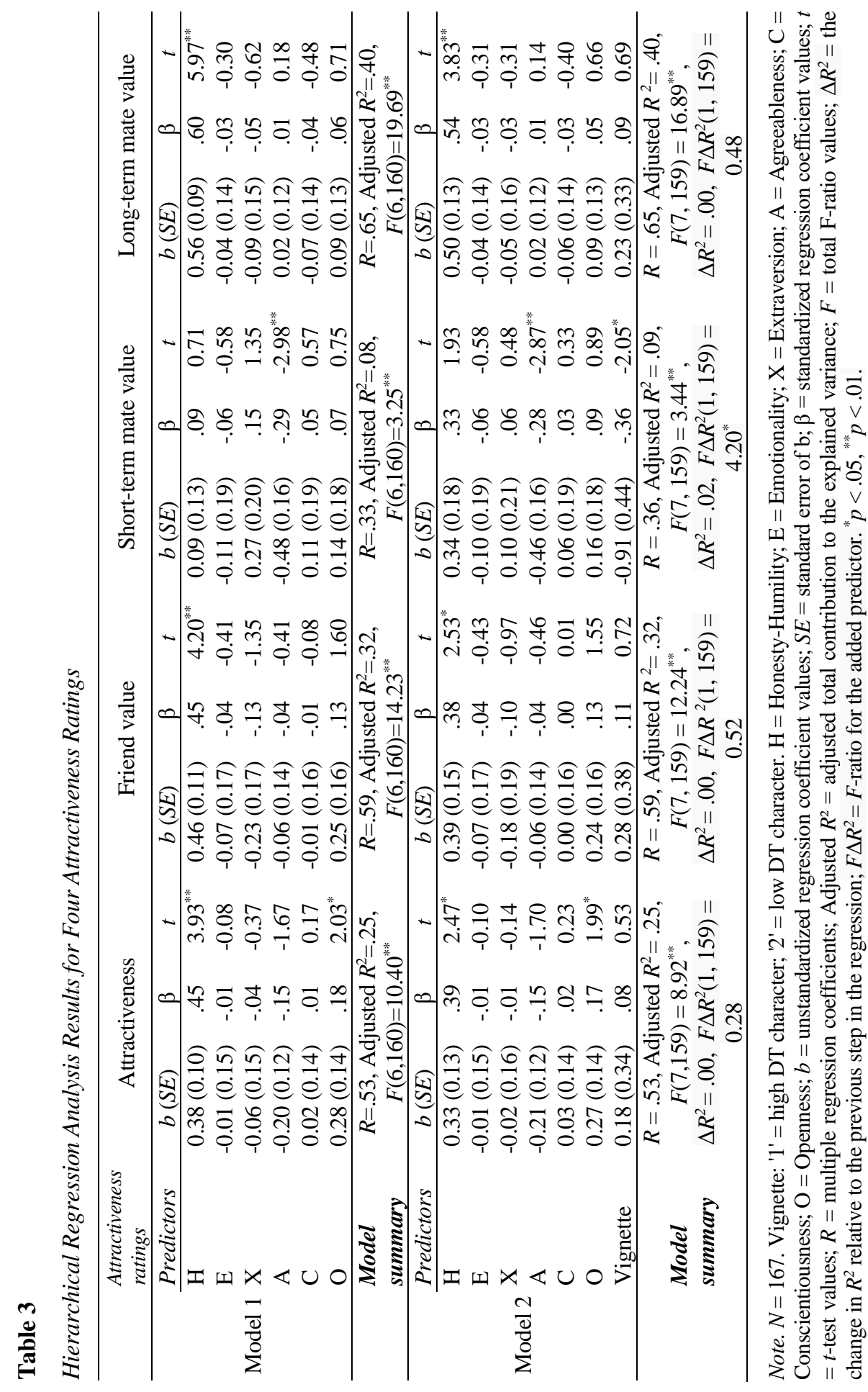


In line with our hypothesis, the participants rated as significantly more attractive the vignette that contained a description of a man with highly expressed DT characteristics only in the short-term mating context. In all of the remaining contexts, the participants rated the low DT character as more attractive than the high DT character. These results are in line with previous studies (Aitken et al., 2013; Jonason et al., 2015), as well as the finding that the high DT character was rated higher on Extraversion and lower on all other traits than the low DT character (Carter et al., 2014; Qureshi et al., 2016). The difference between the two characters was especially pronounced on the personality factor specific to six-factor models, HonestyHumility. The version of the vignette and this factor were also strongly correlated, which is in line with studies indicating a strong association between DT traits and the Honesty-Humility factor (Hodson et al., 2018; Lee and Ashton, 2014). In regression analyses, Honesty-Humility was the only significant predictor in the friendship and long-term relationship contexts and a significant predictor together with Openness for attractiveness. Personality traits explained between $25-40 \%$ of the attractiveness variance. In the attractiveness context, Agreeableness had a suppressor effect. In all these contexts version of the vignette was not a significant predictor after controlling for personality traits. As predicted, version of the vignette had a unique contribution in predicting attractiveness in the short-term mating context after controlling for the basic personality traits from the HEXACO model. However, in this context only $9 \%$ of the variance was explained with both personality traits and the vignette. This is in line with a large-scale study associating Big Five traits with short-term mating in 46 nations finding that personality explained only $4.5 \%$ of the variance (Schmitt \& Shackelford, 2008). Interestingly, Honesty-Humility was not a significant predictor of attractiveness only in the short-term mating context, but due to high correlation with DT traits and no association with the criterion acted as a suppressor variable in the second step when a version of the vignette was added to the analysis. These results would indicate that even though DT traits and HonestyHumility share a large proportion of variance, they have different associations with some criteria and therefore should be both used in the research.

In addition, these findings fit well with the proposition that DT traits represent an evolutionary solution to the adaptive problem of reproduction. Women in our study preferred high DT character in a short-term relationship context which is related to fast life history strategy. This is in line with previous findings showing that DT traits are associated with life history and mating strategies (Jonason et al., 2009, 2017; Jonason, Valentine et al., 2011; Strouts et al., 2017), and that in specific situations women would choose 'bad boys' or 'cads' (Aitken et al., 2013; Jonason et al., 2015). Since fast life history strategy is adopted more in dangerous and unstable environments, choosing a partner with high DT traits could be beneficial in two ways, by having a partner high in DT traits who can better exploit dangerous and unstable environments and/or by having offspring with high DT traits who can better exploit dangerous and unstable environments. Marcinkowska et al. (2016) found that women with a preference for high narcissistic men's faces gave birth to more 
offspring, indicating that in modern society women's preference for some of the DT traits in men may be related to their reproductive success. Nevertheless, not all findings from the studies looking at this subject are in line with this proposition. Aitken et al. (2013) found that men high and low on Machiavellianism were rated equally desirable in the short-term mating context. Qureshi et al. (2016) found that both younger and older women generally rated the low-scoring DT personality as significantly more attractive than the high-scoring DT personality. In a speed-dating situation, none of the DT traits was significantly associated with being chosen as a mate in men (Jauk et al., 2016). However, it could be that women in Qureshi et al. (2016) and Jauk et al. (2016) studies had a more long-term mating context in mind when rating men, which would be in line with our finding that the importance of DT traits changes depending on the relationship context. Therefore, further studies are needed to examine why and when people with high DT traits are desirable mates. In addition, in the short-term mating context personality traits seem to matter the least since only $9 \%$ of the variance was explained compared to $25-40 \%$ in other contexts. Engaging in the short-term mating in women is mainly associated with their own sexual strategy of unrestricted sociosexuality (Muggleton \& Fincher, 2017) and their perceived attractiveness and mate value (Perilloux et al., 2013).

This study also has some limitations. In this study, we treated DT as a composite, although some studies showed that there are differences in perceived attractiveness of the DT traits (e.g. Jauk et al., 2016; Rauthmann \& Kolar, 2013). We decided to use the composite to be able to compare our results with previous findings using such composite measures. In addition, Jonason, Kavanagh et al. (2011) suggested that DT as a latent dimension functions better than separate DT traits in prediction of higher-order traits, such as sociosexuality, or short- or long-term mating orientation. Nevertheless, future studies should examine if results would be different for separate DT traits. The other limitation was that we only examined the attractiveness of males with high DT characteristics, and some studies have indicated that results were different for males and females (Jauk et al., 2016; Jonason et al., 2015). Therefore, future studies should examine the attractiveness of both males and females with high DT characteristics using the HEXACO model to control for basic personality traits.

To conclude, our study compared women's preference for men with high DT characteristics in different relationship contexts and showed that females prefer males with high DT characteristics only in a short-term mating context. In addition, DT personality had a unique contribution in predicting attractiveness in the context of short-term relationship, even after controlling for the basic personality traits from the HEXACO model. This indicates that although DT traits and Honesty-Humility are highly correlated, they are not redundant when predicting certain outcomes. 


\section{References}

Aitken, S. J., Lyons, M., \& Jonason, P. K. (2013). Dads or cads? Women's strategic decisions in the mating game. Personality and Individual Differences, 55(2), 118-122. https://doi.org/10.1016/j.paid.2013.02.017

Ashton, M. C., \& Lee, K. (2009). The HEXACO-60: A short measure of the major dimensions of personality. Journal of Personality Assessment, 91(4), 340-345. https://doi.org/10.1080/00223890902935878

Bourdage, J. S., Lee, K., Ashton, M. C., \& Perry, A. (2007). Big Five and HEXACO model personality correlates of sexuality. Personality and Individual Differences, 43(6), 15061516. https://doi.org/10.1016/j.paid.2007.04.008

Carter, G. L., Campbell, A. C., \& Muncer, S. (2014). The dark triad personality: Attractiveness to women. Personality and Individual Differences, 56, 57-61. https://doi.org/10.1016/j.paid.2013.08.021

Furnham, A., Richards, S. R., \& Paulhus, D. L. (2013). The Dark Triad of personality: A 10 year review. Social and Personality Psychology Compass, 7(3), 199-216. https://doi.org/10.1111/spc3.12018

Gignac, G. E., \& Szodorai, E. T. (2016). Effect size guidelines for individual differences researchers. Personality and Individual Differences, 102, 74-78. https://doi.org/10. 1016/j.paid.2016.06.069

Hodson, G., Book, A., Visser, B. A., Volk, A. A., Ashton, M. C., \& Lee, K. (2018). Is the Dark Triad common factor distinct from low Honesty-Humility? Journal of Research in Personality, 73, 123-129. https://doi.org/10.1016/j.jrp.2017.11.012

Holtzman, N. S., \& Strube, M. J. (2013). People with dark personalities tend to create a physically attractive veneer. Social Psychological and Personality Science, 4(4), 461467. https://doi.org/10.1177/1948550612461284

Jauk, E., Neubauer, A. C., Mairunteregger, T., Pemp, S., Sieber, K. P., \& Rauthmann, J. F. (2016). How alluring are dark personalities? The Dark Triad and attractiveness in speed dating. European Journal of Personality, 30(2), 125-138. https://doi.org/10.1002/ per.2040

Jonason, P. K., Foster, J. D., Egorova, M. S., Parshikova, O., Csathó, Á., Oshio, A., \& Gouveia, V. V. (2017). The Dark Triad traits from a life history perspective in six countries. Frontiers in Psychology, 8, 1476. https://doi.org/10.3389/fpsyg.2017.01476

Jonason, P. K., Kavanagh, P. S., Webster, G. D., \& Fitzgerald, D. (2011). Comparing the measured and latent dark triad: Are three measures better than one. Journal of Methods and Measurement in the Social Sciences, 2(1), 28-44. https://doi.org/10.2458/jmm. v2i1.12363

Jonason, P. K., Koenig, B. L., \& Tost, J. (2010). Living a fast life. Human Nature, 21(4), 428 442. https://doi.org/10.1007/s12110-010-9102-4

Jonason, P. K., Li, N. P., Webster, G. D., \& Schmitt, D. P. (2009). The Dark Triad: Facilitating a short-term mating strategy in men. European Journal of Personality, 23(1), 5-18. https://doi.org/10.1002/per.698 
Jonason, P. K., Lyons, M., \& Blanchard, A. (2015). Birds of a "bad" feather flock together: The Dark Triad and mate choice. Personality and Individual Differences, 78, 34-38. https://doi.org/10.1016/j.paid.2015.01.018

Jonason, P. K., Valentine, K. A., Li, N. P., \& Harbeson, C. L. (2011). Mate-selection and the Dark Triad: Facilitating a short-term mating strategy and creating a volatile environment. Personality and Individual Differences, 51, 759-763. https://doi.org/10. 1016/j.paid.2011.06.025

Jonason, P. K., Webster, G. W., Schmitt, D. P., Li, N. P., \& Crysel, L. (2012). The antihero in popular culture: A Life History Theory of the Dark Triad. Review of General Psychology, 16, 192-199. https://doi.org/10.1037/a0027914

Kaplan, H. S., \& Gangestad, S. W. (2005). Life history theory and evolutionary psychology. In D. M. Buss (Eds.). The handbook of evolutionary psychology (pp. 68-96). Whiley. https://doi.org/10.1002/9780470939376.ch2

Lee, K., \& Ashton, M. C. (2005). Psychopathy, Machiavellianism, and narcissism in the FiveFactor Model and the HEXACO model of personality structure. Personality and Individual Differences, 38(7), 1571-1582. https://doi.org/10.1016/j.paid.2004.09.016

Lee, K., \& Ashton, M. C. (2014). The Dark Triad, the Big Five, and the HEXACO model. Personality and Individual Differences, 67, 2-5. https://doi.org/10.1016/j.paid. 2014.01.048

Lee, K., Ashton, M. C., Wiltshire, J., Bourdage, J. S., Visser, B. A., \& Gallucci, A. (2013). Sex, power, and money: Prediction from the Dark Triad and Honesty-Humility. European Journal of Personality, 27, 169-184. http://dx.doi.org/10.1002/per.1860

Lyons, M., McGrath, L., \& Jonason, P. K. (2012, July 10-14). The desirable dark triad? Evolutionary psychology of why women like bad boys. [Paper presentation]. European Conference on Personality, Trieste, Italy.

Manson, J. H. (2015). Life History Strategy and the HEXACO Personality Dimensions. Evolutionary Psychology, 13(1), 48-66. https://doi.org/10.1177/147470491501300104

Marcinkowska, U. M., Lyons, M. T., \& Helle, S. (2016). Women's reproductive success and the preference for Dark Triad in men's faces. Evolution and Human Behavior, 37(4), 287-292.

Muggleton, N. K., \& Fincher, C. L. (2017). Unrestricted sexuality promotes distinctive shortand long-term mate preferences in women. Personality and Individual Differences, 111, 169-173. https://doi.org/10.1016/j.paid.2017.01.054

Paulhus, D. L., \& Williams, K. M. (2002). The Dark Triad of personality: Narcissism, Machiavellianism, and psychopathy. Journal of Research in Personality, 36(6), 556563. https://doi.org/10.1016/j.evolhumbehav.2016.01.004

Perilloux, C., Cloud, J. M., \& Buss, D. M. (2013). Women's physical attractiveness and shortterm mating strategies. Personality and Individual Differences, 54(4), 490-495. https://doi.org/10.1016/j.paid.2012.10.028

Qureshi, C., Harris, E., \& Atkinson, B. E. (2016). Relationships between age of females and attraction to the Dark Triad personality. Personality and Individual Differences, 95, 200-203. https://doi.org/10.1016/j.paid.2016.02.047 
Rauthmann, J. F., \& Kolar, G. P. (2013). The perceived attractiveness and traits of the Dark Triad: Narcissists are perceived as hot, Machiavellians and psychopaths not. Personality and Individual Differences, 54(5), 582-586. https://doi.org/10.1016/j.paid.2012.11.005

Ryu, E. (2011). Effects of skewness and kurtosis on normal-theory based maximum likelihood test statistic in multilevel structural equation modeling. Behavior Research Methods, 43(4), 1066-1074. https://doi.org/10.3758/s13428-011-0115-7

Schmitt, D. P., \& Shackelford, T. K. (2008). Big Five traits related to short-term mating: From personality to promiscuity across 46 nations. Evolutionary Psychology, 6(2), 246-282. https://doi.org/10.1177/147470490800600204

Sprecher, S., \& Regan, P. C. (2002). Liking some things (in some people) more than others: Partner preferences in romantic relationships and friendships. Journal of Social and Personal Relationships, 19(4), 463-481. https://doi.org/10.1177/0265407502019004048

Strouts, P. H., Brase, G. L., \& Dillon, H. M. (2017). Personality and evolutionary strategies: The relationships between HEXACO traits, mate value, life history strategy, and sociosexuality. Personality and Individual Differences, 115, 128-132. https://doi.org/ 10.1016/j.paid.2016.03.047

Veselka, L., Schermer, J. A., \& Vernon, P. A. (2012). The Dark Triad and an expanded framework of personality. Personality and Individual Differences, 53(4), 417-425. https://doi.org/10.1016/j.paid.2012.01.002

Vittinghoff, E., Glidden, D. V., Shiboski, S. C., \& McCulloch, C. E. (2012). Regression methods in biostatistics: Linear, logistic, survival, and repeated measures models (2nd edition). Springer. https://doi.org/10.1007/978-1-4614-1353-0

\title{
Osobine ličnosti iz modela HEXACO i Mračne trijade kao prediktori privlačnosti muškaraca u različitim odnosima
}

\begin{abstract}
Sažetak
Cilj je istraživanja bio ispitati percipiranu privlačnost osobina ličnosti Mračne trijade u različitim vrstama odnosa (npr. prijateljstvo, kratkoročna veza, dugoročna veza) uz kontrolu osobina ličnosti iz modela HEXACO. U istraživanju je sudjelovalo 167 studentica $(M=20.82$ godina, $S D=1.54)$ koje su procjenjivale ličnost i privlačnost muškarca s visoko $(n=91)$ i nisko $(n=76)$ izraženim osobinama ličnosti Mračne trijade opisanima u vinjetama. U skladu s rezultatima prethodnih istraživanja dobivena je visoka negativna povezanost faktora poštenje - poniznost i visoko izraženih osobina ličnosti Mračne trijade $(r=-.88, p<.001)$. U skladu s hipotezama pronađene su značajne razlike u procjenama privlačnosti muškaraca u različitim interpersonalnim odnosima, pri čemu su muškarci s visoko izraženim osobinama ličnosti Mračne trijade procijenjeni privlačnijima samo u kontekstu kratkoročne veze. Također, u hijerarhijskoj regresijskoj analizi osobine ličnosti Mračne trijade doprinosile su predviđanju privlačnosti povrh osobina ličnosti iz modela HEXACO u kontekstu kratkoročne veze.
\end{abstract}

Ključne riječi: privlačnost, interpersonalni odnosi, Mračna trijada, HEXACO

Primljeno: 26. 10. 2020. 